\title{
ANALISIS PENCATATAN DAN PELAPORAN KEUANGAN PADA SATUAN KERJA PERANGKAT DAERAH (SKPD) BERDASARKAN PERMENDAGRI NOMOR 64 TAHUN 2013 DI PEMERINTAH KOTA MANADO
}

\author{
Desriani N. Tarigan \\ Lidia M. Mawikere \\ Fakultas Ekonomi dan Bisnis, Jurusan Akuntansi \\ Universitas Sam Ratulangi Manado \\ Email: tarigandesriani@ymail.com \\ lidiamawikere76@gmail.com
}

\begin{abstract}
Local Government financial statements are prepared to provide relevant information about the financial position and all transactions carried out by the Local Government during the reporting period. The purpose of this study was to determine whether SKPD Badan Pelaksana Penyuluhan dan Ketahanan Pangan Manado City has been taking notes and preparing financial reporting by Regulation No. 64 of 2013. The analytical method used is descriptive method with qualitative and quantitative data collection in order to understand the data. The results showed SKPD Badan Pelaksana Penyuluhan dan Ketahanan Pangan Manado City in Fiscal Year 2015 to apply accrual accounting system based on Regulation No. 64 Year 2013.
\end{abstract}

Keywords: Analysis, Recording, Reporting, Finance

\section{PENDAHULUAN}

\section{Latar Belakang}

Undang-undang Nomor 32 Tahun 2004 tentang Pemerintahan Daerah tidak sesuai lagi dengan perkembangan keadaan, ketatanegaraan, dan tuntutan penyelenggaraan pemerintahan daerah sehingga perlu diganti dengan berlakunya Undang-undang terbaru yaitu Undang-undang Nomor 23 Tahun 2014. Otonomi Daerah adalah hak, wewenang, dan kewajiban daerah otonom untuk mengatur dan mengurus sendiri Urusan Pemerintahan dan kepentingan masyarakat setempat dalam sistem Negara Kesatuan Republik Indonesia. Urusan Pemerintahan terdiri atas urusan pemerintahan absolut, urusan pemerintahan konkuren, dan urusan pemerintahan umum. Dalam hal ini, Urusan Pemerintahan umum adalah Urusan Pemerintahan yang menjadi kewenangan Presiden sebagai kepala pemerintahan.

Dalam menyelenggarakan sebagian Urusan Pemerintahan yang diserahkan dan/atau ditugaskan, penyelenggara Pemerintahan Daerah mempunyai kewajiban dalam Pengelolaan Keuangan Daerah. Kewajiban penyelenggara Pemerintahan Daerah dalam pengelolaan keuangan daerah meliputi: mengelola dana secara efektif, efisien, transparan dan akuntabel; menyinkronkan pencapaian sasaran program daerah dalam APBD dengan program Pemerintah Pusat; dan melaporkan realisasi pendanaan Urusan Pemerintahan yang ditugaskan sebagai pelaksanaan dari Tugas Pembantuan.

Laporan keuangan Pemerintah Daerah disusun untuk menyediakan informasi yang relevan mengenai posisi keuangan dan seluruh transaksi yang dilakukan oleh Pemerintah Daerah selama satu periode pelaporan. Laporan keuangan Pemerintah Daerah terutama digunakan untuk membandingkan realisasi pendapatan dan belanja dengan anggaran yang telah ditetapkan, menilai kondisi keuangan, menilai efektivitas dan efisiensi Pemerintah Daerah, dan membantu menentukan ketaatannya terhadap peraturan perundang-undangan.

Sebagai pengguna anggaran, SKPD harus menyelenggarakan sistem akuntansi guna menghasilkan laporan keuangan sebagai bentuk pertanggungjawaban penggunaan anggaran yang dikelolanya. Di dalam sistem pengelolaan APBD mengharuskan seluruh penerimaan uang oleh SKPD disetorkan ke rekening Kas Umum Daerah dan pengeluaran dilakukan dari rekening Kas Umum 
Daerah (sering juga disebut Kas Daerah atau sering disingkat Kasda). Pengelola Kasda adalah PPKD yang secara otomatis adalah BUD.

Badan dibentuk untuk melaksanakan fungsi penunjang Urusan Pemerintahan yang menjadi kewenangan Daerah meliputi: perencanaan; keuangan; kepegawaian serta pendidikan dan pelatihan; penelitian dan pengembangan; dan fungsi lain sesuai dengan ketentuan peraturan perundangundangan. Badan Pelaksana Penyuluhan dan Ketahanan Pangan Kota Manado adalah sebuah institusi pemerintah dan unsur pelaksanaan otonomi daerah yang berkewajiban dalam menangani Penyuluhan dan Ketahanan Pangan di lingkup Pemerintah Daerah.

\section{Tujuan Penelitian}

Adapun tujuan yang ingin dicapai dalam penelitian ini adalah untuk mengetahui apakah SKPD Badan Pelaksana Penyuluhan dan Ketahanan Pangan Kota Manado telah melakukan pencatatan dan menyusun pelaporan keuangan berdasarkan Peraturan Menteri Dalam Negeri Nomor 64 Tahun 2013.

Akuntansi

\section{TINJAUAN PUSTAKA}

Menurut Weygandt, Kimmel \& Kieso (2011:7), Akuntansi adalah sistem informasi yang mengidentifikasi, mencatat, dan mengkomunikasikan peristiwa ekonomi dari suatu organisasi kepada pihak yang memiliki kepentingan.

Menurut Warren, Reeve, dan Duchac (2012:3), Akuntansi adalah sebuah sistem informasi yang memberikan laporan kepada pengguna mengenai kegiatan ekonomi dan kondisi dari sebuah bisnis.

\section{Pengelolaan Keuangan Daerah dan APBD}

Pengelolaan Keuangan Daerah adalah keseluruhan kegiatan yang meliputi perencanaan, pelaksanaan, penatausahaan, pelaporan, pertanggungjawaban, dan pengawasan keuangan daerah. Pengelolaan keuangan daerah harus dikelola secara tertib, taat pada peraturan perundang-undangan, efektif, efisien, ekonomis, transparan, dan bertanggung jawab dengan memperhatikan azas keadilan, kepatutan, dan manfaat untuk masyarakat.

Proses pengelolaan keuangan daerah dimulai dengan perencanaan/penyusunan Anggaran Pendapatan Belanja Daerah (APBD). APBD merupakan rencana keuangan tahunan pemerintahan daerah yang dibahas dan disetujui bersama oleh pemerintah daerah dan DPRD, dan ditetapkan dengan peraturan daerah. Peraturan Menteri Dalam Negeri Nomor 21 Tahun 2011, fungsi APBD yang wajib diterapkan dalam setiap penyusunan APBD yaitu:

1. Fungsi Otorisasi

2. Fungsi Perencanaan

3. Fungsi Pengawasan

4. Fungsi Alokasi

5. Fungsi Distribusi

\section{Sistem Akuntansi Satuan Kerja Perangkat Daerah (SKPD)}

Satuan Kerja Perangkat Daerah (SKPD) merupakan unit pemerintahan di lingkungan pemda selaku pengguna anggaran, yang dapat berbentuk dinas, badan, dan kantor ataupun satuan. Sebagai pengguna anggaran, SKPD harus menyelenggarakan sistem akuntansi guna menghasilkan laporan keuangan sebagai bentuk pertanggungjawaban pengguna anggaran yang dikelolanya. Di dalam sistem pengelolaan APBD mengharuskan seluruh penerimaan uang oleh SKPD disetorkan ke rekening Kas Umum Daerah dan pengeluaran dilakukan dari rekening Kas Umum Daerah (istilah Kas Umum Daerah sering juga disebut Kas Daerah atau sering disingkat Kasda). Pengelola Kasda adalah PPKD yang secara otomatis adalah BUD. 


\section{Standar Akuntansi Pemerintahan (SAP)}

Standar Akuntansi Pemerintahan (SAP) ditetapkan dengan Peraturan Pemerintah Nomor 71 Tahun 2010. SAP harus digunakan sebagai acuan dalam menyusun laporan keuangan pemerintah, baik pemerintah pusat maupun pemerintah daerah.

Bentuk dan isi laporan pertanggungjawaban pelaksanaan APBN/APBD disusun dan disajikan sesuai dengan Standar Akuntansi Pemerintahan. Standar Akuntansi Pemerintahan menggunakan basis kas untuk pengakuan transaksi pendapatan, belanja dan pembiayaan, dan basis akrual untuk pengakuan aset, kewajiban, dan ekuitas dana.

Penerapan Peraturan Pemerintah Nomor 71 Tahun 2010 masih bersifat sementara, bahwa selama pengakuan dan pengukuran pendapatan dan belanja berbasis akrual belum dilaksanakan, digunakan pengakuan dan pengukuran berbasis kas. Pengakuan dan pengukuran pendapatan dan belanja berbasis akrual dilaksanakan paling lambat 5 tahun.

\section{Analisis Keuangan Laporan Keuangan Sektor Publik}

Laporan keuangan sektor publik merupakan representasi posisi keuangan dari transaksitransaksi yang dilakukan oleh suatu entitas sektor publik. Tujuan umum pelaporan keuangan adalah untuk memberikan informasi mengenai posisi keuangan, kinerja, dan arus kas dari suatu entitas yang berguna bagi sejumlah besar pemakai (wide range users) dalam membuat dan mengevaluasi keputusan mengenai alokasi sumber daya yang dibutuhkan oleh suatu entitas dalam aktivitasnya untuk mencapai tujuan. Komponen-komponen Laporan Keuangan Sektor Publik:

1. Laporan Realisasi Anggaran (LRA)

2. Laporan Perubahan Saldo Anggaran Lebih (Laporan Perubahan SAL)

3. Neraca

4. Laporan Operasional (LO)

5. Laporan Arus Kas (LAK)

6. Laporan Perubahan Ekuitas (LPE)

7. Catatan atas Laporan Keuangan (CaLK)

\section{Penerapan Standar Akuntansi Pemerintahan Berbasis Akrual}

Penerapan standar akuntansi pemerintahan berbasis akrual ini memiliki ruang lingkup yaitu:

1. Kebijakan Akuntansi Pemerintah Daerah yang terdiri atas:

a. Kebijakan akuntansi pelaporan keuangan

b. Kebijakan akuntansi akun

2. Sistem Akuntansi Pemerintah Daerah (SAPD) memuat pilihan prosedur dan teknik akuntansi dalam melakukan identifikasi transaksi, pencatatan pada jurnal, posting kedalam buku besar, penyusunan neraca saldo serta penyajian laporan keuangan. Sistem Akuntansi Pemerintah Daerah (SAPD) terdiri atas:

a. Sistem Akuntansi PPKD

b. Sistem Akuntansi SKPD

3. Bagan Akun Standar (BAS) merupakan pedoman bagi pemerintah daerah dalam melakukan kodefikasi akun yang menggambarkan struktur laporan keuangan secara lengkap.

\section{Penelitian Terdahulu}

Pajouw (2015) dengan judul Analisis Pencatatan Dan Pelaporan Keuangan Pada Unit Pelaksana Teknis Dinas di Pemerintah Provinsi Sulawesi Utara. Tujuan dari penelitian ini untuk mengetahui pencatatan dan pelaporan keuangan apakah sesuai dengan undang-undang yang berlaku. Metode yang digunakan adalah metode deskriptif. Hasil penelitian menunjukkan UPTD Metrologi Dinas Perindustrian dan Perdagangan telah melakukan proses pencatatan akuntansi, serta pelaporannya telah sesuai dengan PP Nomor 71 Tahun 2010.

Anggraini (2015) dengan judul Analisis Pencatatan dan Pelaporan Keuangan Pada Satuan Kerja Perangkat Daerah (SKPD) di Kota Pariaman (Studi Kasus pada Dinas Koperasi, Perindustrian dan Perdagangan). Tujuan dari penelitian ini untuk mengetahui bagaimana pencatatan dan penyusunan laporan keuangan pada Instansi Pemerintahan, apakah sesuai dengan undang-undang yang berlaku serta kendala apa yang dihadapi dalam pencatatan dan penyusunan laporan keuangan tersebut. Metode yang digunakan adalah metode deskriptif. Hasil penelitian menunjukkan Pencatatan 
dan penyusunan Laporan Keuangan pada Dinas Koperasi, Perindustrian dan Perdagangan telah sesuai dengan Peraturan Menteri Dalam Negeri No. 13 Tahun 2006 tentang Pedoman Pengelolaan Daerah.

\section{Jenis Penelitian}

\section{METODE PENELITIAN}

Jenis penelitian yang digunakan adalah berupa penelitian deskriptif. Peneliti secara langsung mendatangi objek penelitian yaitu di SKPD Badan Pelaksana Penyuluhan dan Ketahanan Pangan Kota Manado untuk memperoleh data-data dan informasi yang dibutuhkan.

\section{Tempat dan Waktu Penelitian}

Penelitian ini dilakukan di SKPD Badan Pelaksana Penyuluhan dan Ketahanan Pangan Kota Manado dengan alamat Jl. A.A Maramis, Paniki Bawah, Kecamatan Mapanget. Adapun waktu penelitian dimulai dari bulan November 2015 sampai dengan selesai.

\section{Prosedur Penelitian}

1. Merumuskan masalah

2. Melakukan studi kepustakaan

3. Mengumpulkan data

4. Mengelolah dan Menyajikan data

5. Menarik kesimpulan dan Memberikan saran

\section{Jenis Data}

Adapun jenis data yang digunakan dalam penulisan dan penyusunan penelitian ini adalah data kualitatif berupa struktur organisasi, tugas dan fungsi dan data kuantitatif berupa laporan keuangan.

\section{Sumber Data}

Sumber data yang digunakan dalam penelitian ini adalah data primer berupa data yang diperoleh melalui wawancara dengan pegawai yang berkaitan dengan bagian keuangan dan data sekunder berupa catatan dan dokumen, sejarah, struktur organisasi dan lain-lain dari objek yang akan diteliti.

\section{Teknik Pengumpulan Data}

Teknik pengumpulan data yang digunakan dalam penelitian ini menggunakan metode:

1. Wawancara yaitu dengan datang langsung ke SKPD Badan Pelaksana Penyuluhan dan Ketahanan Pangan Kota Manado kemudian melakukan wawancara mengenai hal-hal yang berkaitan dengan pencatatan dan pelaporan keuangan.

2. Dokumentasi yaitu dengan melakukan penelusuran dan pengambilan data-data serta dokumen administrasi yang sesuai dan berhubungan dengan penelitian.

\section{Metode Analisis Data}

Metode analisis yang digunakan dalam penelitian ini adalah metode analisis deskriptif dengan pengambilan data kualitatif dan kuantitatif yang bertujuan untuk memahami data.

\section{Gambaran Umum Objek Penelitian}

\section{HASIL PENELITIAN DAN PEMBAHASAN}

Badan Pelaksana Penyuluhan dan Ketahanan Pangan Kota Manado adalah Unit kerja Eselon II yang merupakan salah satu dari 12 (dua belas) Lembaga Teknis yang dibentuk dengan Peraturan Daerah (Perda) Kota Manado Nomor 05 Tahun 2008 Tentang Organisasi dan Tata Kerja Inspektorat, Bappeda, Satuan Polisi Pamong Praja dan Lembaga Teknis Daerah Kota Manado, serta Peraturan Walikota Manado Nomor 39 Tahun 2008 Tentang Rincian Tugas dan Fungsi Badan Pelaksana Penyuluhan dan Ketahanan Pangan Kota Manado. Berdasarkan Peraturan Walikota Manado Nomor 39 Tahun 2008 Badan Pelaksana Penyuluhan dan Ketahanan Pangan (BPPKP) Kota Manado 
mempunyai tugas membantu Walikota dalam Penyelenggaraan sebagian urusan Pemerintahan di Bidang Penyuluhan dan Ketahanan Pangan.

\section{Hasil Penelitian}

\section{Sistem Akuntansi pada SKPD Badan Pelaksana Penyuluhan dan Ketahanan Pangan Kota} Manado

Pendapatan

Badan Pelaksana Penyuluhan dan Ketahanan Pangan Kota Manado merupakan Satuan Kerja Perangkat Daerah (SKPD) yang tidak mengelola penerimaan Pendapatan Asli Daerah (PAD), maka tidak ada pencatatan terhadap pendapatan, sehingga tidak ada bendahara penerimaan pada SKPD Badan Pelaksana Penyuluhan dan Ketahanan Pangan Kota Manado.

Belanja

Belanja adalah semua pengeluaran pada satu periode anggaran. Pengeluaran pada SKPD Badan Pelaksana Penyuluhan dan Ketahanan Pangan Kota Manado di bagi dalam beberapa kelompok, yaitu sebagai berikut:

1. Belanja Operasi yang terdiri atas:

a. Belanja pegawai

b. Belanja barang dan jasa

2. Belanja Modal

Aset

Aset adalah aset tetap yang dikuasai atau digunakan oleh SKPD Badan Pelaksana Penyuluhan dan Ketahanan Pangan Kota Manado, yaitu berupa tanah, peralatan dan mesin, gedung dan bangunan, jalan, jaringan dan instansi, aset tetap lainnya.

\section{Jurnal, Posting ke Buku Besar, Neraca Saldo}

Berikut ini dipaparkan pencatatan/penjurnalan yang disajikan oleh SKPD Badan Pelaksana Penyuluhan dan Ketahanan Pangan Kota Manado (dapat dilihat pada Lampiran):

1. Jurnal Penerimaan Kas

Kas di Bendahara Pengeluaran-Tunai

20.000.000,00

Kas di Bendahara Pengeluaran-Bank $20.000 .000,00$

(Pencairan Dana Uang Persediaan Pada BPPKP Kota Manado)

2. Jurnal Pengeluaran Kas

Uang Muka Operasional

Kas di Bendahara Pengeluaran-Tunai

(Belanja Makan dan Minum Kegiatan Pelatihan Penerapan Teknologi Pertanian/Perkebunan Modern Bercocok Tanam)

Setelah melakukan pencatatan/penjurnalan, maka langkah selanjutnya SKPD Badan Pelaksana Penyuluhan dan Ketahanan Pangan Kota Manado melakukan posting ke buku besar (dapat dilihat pada Lampiran).

Neraca saldo tidak dibuat secara terpisah oleh SKPD Badan Pelaksana Penyuluhan dan Ketahanan Pangan Kota Manado tetapi hanya dalam kertas kerja (worksheet) dan dari kertas kerja tersebut disusun laporan keuangan. (dapat dilihat pada Lampiran).

\section{Laporan Keuangan}

Laporan Keuangan SKPD Badan Pelaksana Penyuluhan Dan Ketahanan Pangan Kota Manado yang terdiri dari Laporan Realisasi Anggaran, Neraca, Laporan Operasional dan Laporan Perubahan Ekuitas. Rincian dari masing-masing laporan tersebut adalah sebagai berikut:

Laporan Realisasi Anggaran

Berdasarkan hasil penelitian, Laporan Realisasi Anggaran SKPD Badan Pelaksana Penyuluhan Dan Ketahanan Pangan Kota Manado Tahun Anggaran 2015 hanya berupa Belanja. Belanja tahun anggaran 2015 dianggarkan sebesar Rp.6.539.051.650,00 dan direalisasikan sebesar 
Rp.6.221.282.735,00 atau 95.14\% dari anggaran. Berikut ini telah dianggarkan dan direalisasikan belanja-belanja pada tahun anggaran 2015:

a. Belanja Operasi dianggarkan sebesar Rp.6.461.285.400,00 dan direalisasi sebesar Rp.6.155.260.735,00 atau 95.26\% dari anggaran.

b. Belanja Modal dianggarkan sebesar Rp.77.766.250,00 dan direalisasi sebesar Rp.66.022.00,00 atau 84.90\% dari anggaran.

Sehingga surplus/defisit anggaran tahun 2015 sebesar Rp.6.539.051.650,00 dan realisasi tahun 2015 sebesar Rp.6.221.282.735,00. Realisasi tahun 2015 mengalami surplus, yaitu pendapatan lebih besar dari belanja. Berikut pos-pos belanja:

1. Belanja Pegawai dianggarkan sebesar Rp.5.091.731.650,00 dan direalisasi sebesar Rp.4.900.148.061,00 atau $96.24 \%$ dari anggaran.

2. Belanja Barang dan Jasa dianggarkan sebesar Rp.1.369.553.750,00 dan direalisasi sebesar Rp.1.255.112.674,00 atau $91.64 \%$ dari anggaran.

3. Belanja Modal dianggarkan sebesar Rp. 77.766.250,00 dan direalisasi sebesar Rp. 66.022.00,00 atau $84.90 \%$ dari anggaran.

Neraca

Berdasarkan hasil penelitian, SKPD Badan Pelaksana Penyuluhan Dan Ketahanan Pangan Kota Manado Tahun Anggaran 2015 menunjukkan bahwa Aset yang dimiliki oleh SKPD Badan Pelaksana Penyuluhan Dan Ketahanan Pangan Kota Manado sebesar Rp.1.663.720.163,00 yang terdiri dari Aset Lancar sebesar Rp.494.596.413,00, Aset Tetap sebesar Rp.1.154.123.750,00 dan Aset Lainnya sebesar Rp.15.000.000,00. Kewajiban yang dimiliki SKPD Badan Pelaksana Penyuluhan Dan Ketahanan Pangan Kota Manado berupa Kewajiban Jangka Pendek sebesar Rp.118.982.720,00. Sedangkan Ekuitas yang dimiliki SKPD Badan Pelaksana Penyuluhan Dan Ketahanan Pangan Kota Manado sebesar Rp.1.544.737.443,00.

Laporan Operasional

Berdasarkan hasil penelitian, Laporan Operasional SKPD Badan Pelaksana Penyuluhan Dan Ketahanan Pangan Kota Manado Tahun Anggaran 2015 menunjukkan bahwa Beban sebesar Rp.5.772.128.062,00 yang terdiri atas Beban Pegawai-LO sebesar Rp.5.005.042.301,00 dan Beban Barang dan Jasa sebesar Rp.767.085.761,00. Penerapan Laporan Operasional pada SKPD Badan Pelaksana Penyuluhan Dan Ketahanan Pangan Kota Manado di mulai pada tahun anggaran 2015, tidak dapat dibandingkan dengan tahun sebelumnya oleh karena itu tidak dapat di ketahui apakah mengalami kenaikan atau penurunan.

Laporan Perubahan Ekuitas

Berdasarkan hasil penelitian, Laporan Perubahan Ekuitas pada SKPD Badan Pelaksana Penyuluhan Dan Ketahanan Pangan Kota Manado Tahun Anggaran 2015 menunjukkan bahwa Ekuitas Awal sebesar Rp.1.095.582.770,00 dan Surplus/Defisit-LO sebesar Rp.5.772.128.062,00 sehingga Ekuitas Akhir sebesar Rp.4.676.545.292,00.

\section{Pembahasan}

SKPD Badan Pelaksana Penyuluhan Dan Ketahanan Pangan Kota Manado pada Tahun Anggaran 2015 menerapkan sistem akuntansi berbasis akrual berdasarkan Permendagri Nomor 64 Tahun 2013 tentang Penerapan Standar Akuntansi Pemerintahan Berbasis Akrual pada Pemerintah Daerah.

Pada pencatatan, SKPD Badan Pelaksana Penyuluhan Dan Ketahanan Pangan Kota Manado melakukan siklus akuntansi mulai dari penjurnalan, posting ke buku besar, dan neraca saldo. Pada pelaporan keuangan, SKPD Badan Pelaksana Penyuluhan Dan Ketahanan Pangan Kota Manado menyusun format laporan keuangan yang terdiri dari Laporan Realisasi Anggaran, Neraca, Laporan Operasional dan Laporan Perubahan Ekuitas dengan terperinci walaupun komponen-komponen yang ada pada laporan keuangan SKPD Badan Pelaksana Penyuluhan dan Ketahanan Pangan Kota Manado belum lengkap (tidak ada Laporan Perubahan Saldo Anggaran Lebih, Laporan Arus Kas, dan Catatan atas Laporan Keuangan).

Dalam pencapaian target yang telah ditetapkan pada tahun 2015 dan proses pencatatan dan pelaporan keuangan, SKPD Badan Pelaksana Penyuluhan dan Ketahanan Pangan Kota Manado tidak 
memiliki hambatan dan kendala yang cukup berarti dalam pengelolaannya. SKPD Badan Pelaksana Penyuluhan dan Ketahanan Pangan Kota Manado berkoordinasi dengan PEMKOT Manado dalam penerapan sistem akuntansi berbasis akrual pada pencatatan dan pelaporan keuangan SKPD Badan Pelaksana Penyuluhan dan Ketahanan Pangan Kota Manado.

\section{Kesimpulan}

\section{PENUTUP}

Kesimpulan penelitian sebagai berikut:

1. SKPD Badan Pelaksana Penyuluhan Dan Ketahanan Pangan Kota Manado pada Tahun Anggaran 2015 sudah menerapkan sistem akuntansi berbasis akrual berdasarkan Permendagri Nomor 64 Tahun 2013 tentang Penerapan Standar Akuntansi Pemerintahan Berbasis Akrual pada Pemerintah Daerah.

2. SKPD Badan Pelaksana Penyuluhan Dan Ketahanan Pangan Kota Manado melakukan pencatatan siklus akuntansi mulai dari penjurnalan, posting ke buku besar, dan neraca saldo.

3. SKPD Badan Pelaksana Penyuluhan Dan Ketahanan Pangan Kota Manado menyusun format laporan keuangan dengan terperinci walaupun komponen-komponen yang ada pada laporan keuangan SKPD Badan Pelaksana Penyuluhan dan Ketahanan Pangan Kota Manado belum lengkap (tidak ada laporan perubahan saldo anggaran lebih, laporan arus kas, dan catatan atas laporan keuangan).

\section{Saran}

Hal yang perlu diperhatikan oleh SKPD Badan Pelaksana Penyuluhan dan Ketahanan Pangan Kota Manado yaitu:

1. Untuk tahun anggaran 2016 dan seterusnya, sebaiknya SKPD Badan Pelaksana Penyuluhan dan Ketahanan Pangan Kota Manado telah berpedoman sepenuhnya pada peraturan yang berlaku.

2. Perlu adanya sumber daya manusia/pegawai yang spesialis dalam bidang laporan keuangan dalam pembuatan pelaporan keuangan.

\section{DAFTAR PUSTAKA}

Anggraini, 2015. Analisis Pencatatan dan Pelaporan Keuangan pada Satuan Kerja

Perangkat Daerah (SKPD) di Kotapariaman (Studi Kasus pada Dinas

Perindustrian, dan Perdagangan).

Modul Akuntansi Keuangan Pemerintah Daerah dan Satuan Kerja Perangkat Daerah 2014.

Pajouw, 2015. Analisis Pencatatan dan Pelaporan Keuangan pada Unit Pelaksana Teknis Dinas di Pemerintahan Provinsi Sulawesi Utara.

Peraturan Menteri Dalam Negeri Nomor 21 Tahun 2011 tentang Anggaran Pendapatan Belanja Daerah.

Peraturan Menteri Dalam Negeri Nomor 64 Tahun 2013 tentang Penerapan Standar Akuntansi Pemerintahan Berbasis Akrual Pada Pemerintahan Daerah.

Peraturan Pemerintah Nomor 71 Tahun 2010 tentang Standar Akuntansi Pemerintahan (SAP).

Profil Badan Pelaksana Penyuluhan dan Ketahanan Pangan Kota Manado Tahun 2013. Undang-undang Nomor 23 Tahun 2014 tentang Pemerintahan Derah.

Warren, Carl S, Reeve, James. M, dan Duchac Jonathan E, 2012. Corporate Financial Accounting 11 Edition. Canada: South Western Cengange Learning.

Weygandt, Jerry. J, Donald E. Kieso \& Paul D. Kimmel, 2011. Pengantar Akuntansi, Edisi 7, Buku 2. Jakarta: Salemba Empat. 